\title{
Memes enquanto \\ tecnoimagens: um olhar \\ sob o prisma das teorias de Vilém Flusser
}

Arthur de Oliveira Rocha

Doutorando; Universidade Federal do Rio Grande do Norte, Natal, RN, Brasil

arthurd.oliveira@hotmail.com

\section{Maria do Socorro Furtado Veloso}

Doutora; Universidade Federal do Rio Grande do Norte, Natal, RN, Brasil

socorroveloso@uol.com.br

\section{Resumo}

Os memes são unidades culturais replicantes e virais que se converteram em itens digitais e em gênero midiático, atualmente em profusão na internet. Sua produção, consumo e circulação configuram-se como práticas sociais. Este artigo, que se utiliza de pesquisa bibliográfica, tem como objetivo compreender e discutir o fenômeno dos memes segundo as ideias do filósofo tcheco Vilém Flusser acerca das imagens na pós-modernidade, denominadas por ele de "tecnoimagens" ou "imagens técnicas". Os memes de internet se apresentam, então, como uma forma de linguagem típica da comunicação pós-moderna e como uma prática da cultura digital inserida no que o autor chama de pós-história.

\section{Palavras-chave}

Mídia. Meme. Imagens técnicas. Tecnoimagens. Flusser.

\section{Introdução}

Na história da cultura do Ocidente, a invenção da prensa de tipos móveis por Gutenberg, no século XV, demarcou o início da era da imprensa, fortalecendo a escrita como forma de expressão materializada e passível de reprodução em série. Esse cenário perdurou até o surgimento de aparelhos que permitiam o registro visual fotográfico e fílmico, no século XIX, que resultou na sociedade imagética característica da pós-modernidade. Certamente a imagem, como elemento de mediação da vida humana, não é fenômeno típico 
das sociedades pós-modernas. Contudo, suas diferentes formas de representação nunca foram tantas, tão recorrentes e tão centrais.

0 pensador tcheco Vilém Flusser, que residiu por 32 anos no Brasil (1940-1972), dedicou grande parte de sua vida ao estudo dos meios da comunicação e da cultura no século XX. Flusser teorizou acerca dessa sociedade das imagens - denominadas por ele de tecnoimagens. As imagens técnicas, como ele também as nomeia, são geradas e visualizáveis apenas por meio de dispositivos técnicos. Não possuem dimensões físicas ou materiais e tomaram o lugar da escrita no protagonismo da representação simbólica das sociedades, provocando uma revolução da cultura. Tal revolução marca o início de uma nova era, a qual Flusser chama de pós-história - conceito que será aprofundado adiante.

No período precedente à invenção da escrita, as pinturas e gravuras rupestres evidenciam, para Santaella e Nöth (2013, p. 133), a constante obsessão do ser humano por reproduzir o visível e representar o imaginário. Na contemporaneidade, um tipo de representação imagética atende de maneira significativa a essa obsessão humana de que tratam Santaella e Nöth: os memes. Estes podem ser entendidos como replicadores, como unidades de cultura ou como itens digitais, que se multiplicam incessantemente. Seu objetivo é perpetuar-se no repertório cultural dos indivíduos (atores sociais) através da propagação de pessoa para pessoa, valendo-se de estratégias que possam garantir maior alcance em menos tempo.

Tais elementos se misturam e se ressignificam entre si, reinventando-se, como numa mutação, e esse aspecto auxilia os memes a não se tornarem obsoletos ou facilmente perecíveis. 0 meme se apresenta hoje como um dos fortes elementos imagéticos utilizados nos meios virtuais para reproduzir o que se vê e representar o que se imagina. Os memes surgem do cotidiano, das coisas mais banais da vida em sociedade, e as pessoas consomem e compartilham esse tipo de conteúdo porque se identificam; porque o meme representa o que as pessoas, em alguma medida, imaginam; porque reproduz o que elas veem em casa, no trabalho, nas instituições que frequentam, nas mídias, nos grupos sociais de que fazem parte.

Os memes são um dos gêneros midiáticos que se destacam nas formas de comunicação difundidas pela internet, apresentando-se enquanto linguagem utilizada de modo recorrente pelos "escritores" da pós-história de que fala Flusser. Por meio de pesquisa bibliográfica e de inferências geradas a partir do cruzamento de obras e conceitos, este artigo apresenta reflexões sobre os memes que vão desde sua concepção inicial 
(BLACKMORE, 2000; DAWKINS, 2007) até o modo como são gerados e como circulam na internet (FONTANELLA, 2009; SHIFMAN, 2013), assunto em que se centra este trabalho. Também se debruça sobre as discussões de Vilém Flusser $(2008,2011,2014)$ acerca das imagens na pós-modernidade, relacionando suas ideias a respeito das imagens técnicas, de escala da abstração, de nulodimensionalidade, de cultura da imagem e de sociedade telemática com os memes.

\section{A cultura dos memes}

Na web, a produção de conteúdos humorísticos cresce exponencialmente, alçada por fatores como a convergência digital ${ }^{1}$, a inteligência coletiva $^{2}$ e a cultura participativa ${ }^{3}$, associados ao acesso cada vez mais simples a ferramentas para produção e veiculação desses conteúdos, uma vez que qualquer usuário pode se tornar produtor - lógica do DIY4. Em meio a tantas e tão variadas produções, destacam-se os memes.

A popularização dos memes é um fenômeno típico da era digital, alavancado pelo que Jenkins (2009) chama de "cultura do espalhável"5. Eles exercem efeitos no público em razão do tom satírico ou irônico e podem descambar para o riso. À primeira vista, podem parecer apenas uma piada bem contada, mas a comicidade crítica presente em muitos deles é capaz de gerar grande poder de mobilização e articulação nas redes digitais.

Os memes são um gênero discursivo midiático amplamente produzido, disseminado e consumido principalmente por meio dessas redes. Tais processos se dão através dos sujeitos inseridos no que Lipovetsky (2005) chama de "sociedade humorística", típica da modernidade. Os memes podem ser entendidos como uma nova maneira de se informar

\footnotetext{
${ }^{1}$ Integração de mídias diferentes que convergem para criar um ambiente único e próprio, possibilitando o desenvolvimento de uma cultura da convergência. Para Jenkins (2009, p. 29), fluxo de conteúdos através de múltiplas plataformas de mídia, no qual está presente a cooperação entre múltiplos mercados midiáticos e o comportamento migratório do público. Envolve transformações tecnológicas, mercadológicas, culturais e sociais.

2 Inteligência compartilhada que surge com a colaboração de inúmeros indivíduos em suas diversidades; inteligência na qual o conhecimento está compartilhado na humanidade: ninguém sabe de tudo, mas todo mundo sabe de algo. Expressão cunhada pelo teórico francês Pierre Lévy. Para Jenkins (2009, p. 30,57), a inteligência coletiva pode ser vista como uma fonte alternativa de poder midiático e refere-se à capacidade das comunidades virtuais de alavancar a expertise combinada de seus membros, a uma soma total de informações retidas individualmente pelos membros do grupo e que podem ser acessadas em resposta a uma pergunta específica.

${ }^{3} \mathrm{Na}$ cultura participativa, o usuário deixa o status de mero receptor para ser um usuário produtor de conteúdo. Essa atividade é possibilitada com a adesão e uso da mídia digital, internet e redes sociais. A cultura participativa contrasta, explica Jenkins (2009, p. 30), com noções mais antigas sobre a passividade dos receptores dos meios de comunicação. Em vez de falar sobre produtores e consumidores de mídia como ocupantes de papéis separados, podemos agora considerá-los como participantes.

${ }^{4}$ Do It Yourself (faça você mesmo).

${ }^{5}$ Spreadable media. Potencial do público, tanto do ponto de vista técnico quanto cultural, de compartilhar conteúdos segundo seus próprios interesses.
} 
sobre o mundo, bem como uma forma de manifestar opinião sobre determinado acontecimento.

O conceito de meme foi cunhado pelo biólogo Richard Dawkins no livro The selfish gene (O gene egoísta), lançado originalmente em 1976. No livro, o pesquisador discute a difusão e evolução cultural, sob um prisma sociobiológico. Dawkins faz um paralelo entre a transmissão de valores culturais (meme) e a genética (gene). Para o autor, os genes possuem papel de entidade replicadora, transmitindo características genéticas entre indivíduos, enquanto o meme seria uma unidade replicadora, mas de transmissão cultural.

0 termo tem origem na palavra grega mimesis (imitação). Para sonoramente aproximar o termo à palavra "gene", o autor o abreviou para "meme". Segundo Dawkins, que é adepto da perspectiva darwinista, os memes estariam sujeitos a um processo de evolução similar ao da seleção natural:

Tal como os genes se propagam no pool gênico saltando de corpo para corpo através dos espermatozoides ou dos óvulos, os memes também se propagam no pool de memes, saltando de cérebro para cérebro através de um processo que, num sentido amplo, pode ser chamado de imitação. (DAWKINS, 2007, p. 330).

Os memes seriam, para Dawkins, elementos que competem entre si, já que sua sobrevivência dependeria da extinção dos demais, daí a razão da adjetivação "egoísta". Os memes estariam, portanto, em ininterrupta disputa pela atenção e uso por parte dos indivíduos. Para o pesquisador, a replicação memética ocorreria de forma autônoma e cega, e os memes teriam apenas o objetivo de se replicar e sobreviver. A transmissão memética, a partir da imitação, está "sujeita à contínua mutação e também combinação" (DAWKINS, 2007, p. 195), uma vez que os memes se perpetuam tanto por cópias completamente idênticas, quanto por recombinação e ressignificação. Os memes são extremamente mutáveis, e é a cópia com diferenciação que possibilita a variabilidade memética.

Os elementos da cultura só se configuram enquanto tais se forem passados adiante e se estiverem presentes e forem próprios de um determinado grupo. Logo, o meme, sendo um replicador de unidades culturais, funcionaria como uma forma de aprendizagem social. 0 autor explica também que, a cada geração, a contribuição dos genes é reduzida pela metade, ganhando proporções insignificantes ao longo do tempo. No caso de um meme, a longevidade pode ser bem maior. "Se você contribuir para a cultura mundial, se você tiver 
uma boa ideia, compor uma melodia, inventar uma vela de ignição, escrever um poema, isso pode perdurar, intacto, muito tempo depois que seus genes foram dissolvidos" (DAWKINS, 2007, p. 199).

Depois de Dawkins dar os primeiros passos do que viria a se tornar a ciência que estuda a replicação, a propagação e a evolução dos memes, os estudos sobre memética foram explorados por outros pesquisadores de diversas áreas. É o caso de Susan Blackmore, no livro The meme machine (A máquina memética, 2000). Ela continua trabalhando com o viés sociobiológico, mas enfatiza a autonomia. Blackmore (2000) concebe meme como uma ideia, instrução, comportamento, pedaço de informação, estilo ou uso de algo que se espalha de pessoa para pessoa dentro de uma determinada cultura. Ou seja, o meme pode ser um mito, uma gíria, um estilo arquitetônico, uma tendência de moda, uma música, uma religião. Para a autora, “quando você imita alguém, algo é passado adiante. Esse 'algo' pode então ser passado adiante de novo e de novo até que ganha vida própria" (BLACKMORE, 2000, p.4, tradução nossa) ${ }^{6}$.

Para que um meme possa se multiplicar, ele precisa, de alguma forma, alcançar um indivíduo a partir de outro. Nos primórdios da humanidade, isso se dava pela observação, pelos desenhos nas paredes das cavernas, e depois por meio da comunicação oral, quando passamos a dominar a fala. Daí surgiram inúmeras outras possibilidades, de acordo com a evolução do homem e com seu domínio sobre as tecnologias - os papiros, os livros, as ondas sonoras, as mídias em geral, até o meio digital. "O telégrafo, o telefone, o rádio e a televisão são todos passos em direção ao espalhamento mais efetivo dos memes", afirma Blackmore (2000, p. 212, tradução nossa) ${ }^{7}$. Dawkins acredita que foram os próprios replicadores que impulsionaram a criação de tais sistemas e máquinas, com vistas a sua replicação continuada e melhorada. Encontramos, pois, na era digital, as condições mais favoráveis, até então, para a multiplicação e espalhamento dessas unidades.

Para Susan Blackmore (2000), os seres humanos seriam como hospedeiros, uma espécie de "máquina memética" (vem daí o título de sua obra) com a função de acolher e propagar os memes. Essa perspectiva estuda o comportamento e a cultura a partir da biologia, minimizando a ação dos indivíduos no processo de replicação, deixando-lhes apenas o encargo de hospedeiros.

\footnotetext{
6 "When you imitate someone else, something is passed on. This 'something' can then be passed on again, and again, and so take on a life of its own"

7 "The telegraph and telephone, radio and television, are all steps towards spreading memes more effectively"
} 
As concepções de "meme" de Dawkins e de Blackmore são distintas, portanto, daquela que entende meme como "itens digitais" (SHIFMAN, 2013), como gênero midiático de conteúdos geralmente cômicos propagados em ambientes online e de rápida popularização (os chamados conteúdos viraisº). Essa atualização do termo, que acabou se popularizando entre os usuários da internet, se deu com o avanço da internet 2.0 e das redes sociais digitais. As redes impulsionam a propagação de conceitos e ideias, oferecendo insumos e um terreno fértil para os memes, que utilizam a internet como meio estratégico para alcançar seu objetivo basilar: a perpetuação.

Trata-se, para Dawkins, de um sequestro da ideia original do termo, pois, ao invés de sofrer mutação e espalhar-se por seleção darwiniana, os memes de internet são alterados de maneira intencional pela criatividade humana, ou seja, o homem não ocupa papel apenas de hospedeiro. A web deixou de ser uma potencial ecologia perfeita para a replicação memética: “[...] tornou-se ela mesma um grande e complexo ecossistema memético diverso daquela acepção inicial, mas que ainda mantém algumas interfaces, no qual é mister entender as pessoas como agentes ativas no processo de alteração do meme no curso de sua difusão." (OLIVEIRA, 2016, p. 61).

A pesquisadora Limor Shifman, no livro Memes in digital culture (Memes na cultura digital) (SHIFMAN, 2013), explica que os memes são itens digitais que compartilham características de conteúdo, de forma ou de postura; que são criados com consciência uns dos outros e que são veiculados, imitados e transformados por diversos usuários (SHIFMAN, 2013, p. 455). Fontanella (2009, p. 9) afirma que o meme seria como um "molde comum" ou "modelo formal básico" rapidamente assimilado, copiado e repetido, do qual são geradas versões e variações, ou mesmo evoluções, e que se espalha de pessoa para pessoa de maneira viral. 0 meme da internet perdura enquanto suas cópias se espalham, sendo essas mais importantes que o original (SHIFMAN, 2013, p. 373).

Para Shifman, os memes possuem três características-chave que possibilitam seu sucesso na cultura digital. Primeiro, propagam-se de forma gradual, de indivíduo para indivíduo, até se tornarem um fenômeno social compartilhado, (característica altamente compatível com a cultura da web 2.0), de usuários produtores compartilhando seus conteúdos com outros internautas. A segunda característica-chave é a reprodução através de várias formas de reinterpretação ou imitação. Mesmo com a possibilidade de apenas

${ }^{8} \mathrm{~A}$ viralidade é uma das características basilares para a existência dos memes; portanto, viral não é sinônimo de meme. 
compartilhar o conteúdo memético, muitos usuários optam por criar suas próprias versões, utilizando técnicas como o remix e a imitação/paródia (SHIFMAN, 2013, p. 266). A terceira estaria relacionada ao processo de competição e seleção pelo qual os memes passam no momento de se reproduzirem.

Os memes são marcados pela aura do digital trash (PRIMO, 2007), característica comum aos conteúdos do ecossistema digital. 0 digital trash trabalha com a estética do grotesco ${ }^{9}$, o que dá um caráter orgânico/artesanal aos memes, tornando-os mais acessíveis tanto do ponto de vista da produção quanto do consumo. Trata-se de um estilo de produção de conteúdo intencionalmente tosco, grosseiro, mal-acabado.

Como os memes estão sempre em processo contínuo de transformação e reformulação, podemos entendê-los como mensagens abertas, nunca completas, uma vez que estão disponíveis para apropriações, usos, modificações, combinações, remixagens e novas contextualizações. Nesse sentido, tais replicadores digitais se apresentam como propriedade comum a todos, não exclusiva de seus criadores, e fica até mesmo difícil estabelecer ou identificar um "criador" ou "autor", haja vista que no contexto da cultura participativa na qual estamos inseridos, as fronteiras entre produção e consumo de conteúdo se tornam tênues e embaçadas.

\section{Flusser e as imagens técnicas}

No livro $O$ universo das imagens técnicas (2008), o filósofo tcheco Vilém Flusser tece críticas à sociedade pós-moderna, complementando, aprofundando e redirecionando seu livro mais conhecido, A filosofia da caixa preta (2011). O pensador nos apresenta sua teoria sobre as imagens técnicas, como também a ideia de "escala da abstração". As tecnoimagens, como também as denomina, seriam as imagens da pós-escrita: não mais feitas de planos ou superfícies, mas de pontos, grânulos e pixels, da ordem do grau zero do espaço. A escala da abstração se refere à subtração das dimensões dos objetos até chegarmos às tecnoimagens, saindo da tridimensionalidade até a nulodimensionalidade, que seria o último estágio.

As imagens técnicas são compreendidas por Flusser como entidades sem corporeidade, justamente por apresentarem nenhuma dimensão. É a emergência delas que caracteriza a revolução cultural apresentada por Flusser em sua obra. 0 papel de portador

${ }^{9}$ Questão abordada na obra de Sodré e Paiva (2002). 
da informação, antes desempenhado primordialmente pelo texto escrito, passa a ser assumido pelas tecnoimagens.

Para Flusser, a manipulação é o gesto primordial, que abstrai o tempo do mundo concreto, garantido o seu registro. No caso de um registro imagético, as imagens abstraem a profundidade dos fenômenos e os fixam em planos, superfícies, transformando-os em cenas. A imagem passa, então, a mediar o homem e o fenômeno palpável. É necessário distinguir as imagens ditas tradicionais das imagens técnicas:

A imagem tradicional é produzida por gesto que abstrai a profundidade da circunstância, isto é, por gesto que vai do concreto rumo ao abstrato. A tecno-imagem é produzida por gesto que reagrupa pontos para formarem superfícies, isto é, por gesto que vai do abstrato rumo ao concreto. (FLUSSER, 2008, p. 17).

Quanto ao produtor de imagens técnicas, diferentemente do produtor das imagens tradicionais, ele se vê tendo de desempenhar gestos jamais realizados. Suas mãos não se dirigem mais contra objetos, mas sim contra superfícies. 0 ato de agrupar pontos de dimensão zero é inviável para mãos, olhos ou dedos sem o auxílio de instrumentos apropriados. Desse modo, as imagens técnicas surgem com a invenção de aparelhos que possam juntar automaticamente tais elementos pontuais, de acordo com os comandos emitidos pelo homem, de modo que tais apetrechos possam imaginar por nós o inimaginável.

A imagem técnica é condicionada a ser produzida e visualizada apenas mediante tais aparelhos, "[...] programados para transformar possibilidades invisíveis em improbabilidades visíveis." (FLUSSER, 2008, p. 24). Os aparelhos produtores de imagens técnicas seriam uma espécie de busca do ser humano pela imortalidade. São previamente programados para desempenhar determinadas funções, e os usuários de tais aparelhos apenas podem produzir tecnoimagens, dentro das possibilidades de criação já estabelecidas. Flusser usa o exemplo de um fotógrafo com sua câmera: “Todas as imagens que o fotógrafo produz são, em tese, futuráveis para quem calculou o programa do aparelho. São imagens 'prováveis'” (2008, p. 26). 0 seu desafio seria o de fazer imagens pouco prováveis do ponto de vista do programa dos aparelhos, agindo contra o programa no "interior" do próprio programa. 
No processo de produção das imagens técnicas, Flusser diz que se trata de um gesto não transparente, uma vez que - aproveitando ainda o exemplo do fotógrafo e sua câmera -, através do movimento das pontas dos dedos, o sujeito aciona comandos que, no interior da "caixa-preta", computarão as unidades a fim de agrupá-las. Sendo assim, o usuário do aparelho não sabe exatamente de que forma ocorre toda a mágica da programação até gerar o resultado final; ele apenas a utiliza. Isso difere da produção de imagens tradicionais, porque tal gesto de criação seria transparente aos sujeitos.

A nova superficialidade desiste da tarefa de elucidar a pretidão das caixas; ela relega, com leve desprezo, a tarefa aos físicos e técnicos que inventaram e fabricaram os aparelhos. A nova superficialidade se interessa pelo input e pelo output das caixas pretas, se interessa pela intenção dos imaginadores [usuários] ao apertarem as teclas (FLUSSER, 2008, p. 41).

As imagens técnicas não são superfícies efetivas, são superfícies aparentes, haja vista serem cheias de intervalos, espaços vazios entre os infinitos pontos que as compõem. Observadas à distância, enganam os nossos olhos para que não percebamos tais intervalos. Contudo, a uma aproximação máxima, é possível verificar os referidos espaços.

É válido ressaltar que, para o autor, todo gesto de criação de imagens técnicas está submetido às pontas dos dedos, uma vez que as tecnoimagens são geradas no interior de aparelhos por meio de comandos acionados por teclas. Para ele, há basicamente dois tipos de teclas, aquelas que publicam o privado (output) e as que privatizam o púbico (input). Um cinegrafista utiliza teclas da câmera para registrar uma determinada cena. Ele grava privatizando o fato público. Depois, outras teclas serão usadas na emissora de TV para publicar a imagem até então privada. Em casa, o espectador aciona mais teclas para, novamente, privatizar a imagem publicada que recebeu no seu aparelho televisor.

\section{Memes e tecnoimagens na pós-história}

Vilém Flusser se interessa pelas questões filosóficas, em especial fenomenológicas, no sentido de desvendar o papel das mídias na (de)codificação do mundo pós-moderno. Ele entende código como um sistema de símbolos que torna possível a comunicação entre pessoas. Os símbolos são fenômenos que substituem/representam outros fenômenos. É o que faz a comunicação: ela substitui, representando. As pessoas se comunicam, se fazem 
compreensíveis, através de códigos. No ambiente de virtualidade das mídias digitais, os usuários utilizam os memes enquanto código para realizarem suas comunicações.

Flusser identifica que as mudanças antropológicas essenciais são reflexos das mudanças nos códigos dominantes em cada época da história. 0 autor propõe duas revoluções fundamentais na cultura ocidental: a imagem e o texto. Os fenômenos do mundo eram codificados inicialmente em imagens pictóricas, como as pinturas rupestres; depois, foram representados através da linearidade intrínseca ao código da escrita e do texto; agora, é a codificação binária e alfanumérica que predomina no bombardeio de imagens técnicas ao qual estamos submetidos diariamente. No meio desse bombardeio estão os memes de internet, que entenderemos aqui como um tipo de imagem técnica.

As primeiras imagens pictóricas, como as pinturas rupestres, podem ser consideradas "[...] superfícies que pretendem representar algo. Na maioria dos casos, algo que se encontra lá fora no espaço e no tempo." (FLUSSER, 2011, p. 21). Temos, portanto, a representação imagética como resultado de uma abstração de dimensões espaçotemporais para transmutar o fenômeno da vida real (tridimensional) para a superfície de uma parede de pedra de uma caverna (na dimensão apenas do plano), por exemplo.

Quando se observa uma imagem da qual alguma de suas dimensões foi removida, é necessário reincorporar tais dimensões abstraídas, a fim de gerar sentido. "Os eventos do real substituídos pelas cenas formadas pictoricamente criam, portanto, um nível de consciência novo, o imaginativo, capaz da dupla tarefa de codificar as circunstâncias em símbolos e de decodificar símbolos em circunstâncias" (OLIVEIRA, 2016, p. 21). Quando um internauta acessa suas redes sociais e se depara com um meme, ele faz exatamente esse movimento de devolver as três dimensões daquela imagem em pixels, de dimensão nula.

Para Flusser, com o advento das imagens técnicas, entramos num processo de revolução cultural, adentrando o que o autor denomina de pós-história. Juracy Oliveira explica:

A ideia de Pós-história flusseriana longe de implicar o fim da história e dos seus processos de mudança, tal qual propôs Fukuyama, representa, na verdade, um novo momento de codificação cultural, dessa vez técnico, caracterizado pelo fim da consciência história como forma dominante de pensamento. Assim, os eventos deixam de ser interpretados de maneira linear como outrora (OLIVEIRA, 2016, p. 26). 
Com o advento da escrita e o início da história humana, temos o alinhamento das imagens pictóricas em textos. Na pós-história, com as tecnoimagens, os textos (lineares) são transcodificados em cenas imaginísticas. "Historicamente, as imagens tradicionais são préhistóricas; as imagens técnicas são pós-históricas. Ontologicamente, as imagens tradicionais imaginam o mundo; as imagens técnicas imaginam textos que concebem imagens que imaginam o mundo" (FLUSSER, 2011, p. 29-30).

Para o filósofo, as imagens técnicas, baseadas em códigos binários, avançam contra a linearidade do texto de modo a substituí-lo por um pensamento cibernético. Faz parte desse novo pensar a ideia de coletivo, contributivo e participativo, mencionado anteriormente. Como já dito, os memes de internet atuam hoje como uma nova forma de se comunicar e tal comunicação se expressa através dessa forma cibernética de pensar. "A densidade semântica dessas imagens carregaria mais informação do que a linha escrita jamais pode [sic], de modo que as imagens manipuladas telematicamente dariam vazão a um diálogo pictórico extremamente mais rico do que o linear" (OLIVEIRA, 2016, p. 46).

É válido destacar alguns aspectos que diferenciam as imagens feitas por dispositivos técnicos das imagens precedentes. O ponto crucial do que Lucia Santaella e Winfried Nöth (2013) denominam de imagens pré-fotográficas, que seriam as imagens não técnicas de Flusser - o desenho, a pintura e a gravura -, é a existência de uma materialidade no suporte em que essas imagens estão presentes. Esse componente físico é que possibilita a existência da imagem pré-fotográfica, através do registro e compartilhamento.

Devido à especificidade do suporte em que se materializam, essas imagens "[...] carregam um caráter de unicidade, são objetos únicos que precisam de reclusão como forma de assegurar a sua conservação; assim, para escapar da perecibilidade mundana, elas adentram os espaços dos templos, dos museus, das galerias etc." (SANTAELLA; NÖTH, 2013, p. 178). Pela mesma razão, as imagens pré-fotográficas se tornam de mais difícil acesso às pessoas em geral, por existirem em quantidades limitadas e por estarem armazenadas em locais de maior zelo e restrição, o que nos leva a lembrar a ideia de "aura", abordada por Walter Benjamin em seu ensaio $A$ obra de arte na era de sua reprodutibilidade técnica (2015), publicado originalmente em 1936.

Tudo isso é notadamente o oposto do fenômeno dos memes de internet. Eles não estão nos templos, nos museus e nas galerias convencionais. Vão na contramão de qualquer pensamento envolvendo autenticidade ou existência de uma "aura", visto que uma de suas 
características mais basilares é a de espalhamento e reprodução em série, seja por cópias fidedignas, seja por cópias ressignificadas por novos elementos.

Com a derrocada da "aura" na obra de arte, implicada no surgimento da fotografia, a reprodutibilidade técnica fragiliza as ideias de autoria, de direito de autor e de propriedade intelectual. Diante da premissa dos memes como mensagens abertas, disponíveis para apropriação e ressignificação, e da ideia de cultura participativa, torna-se dispensável saber a autoria de determinado meme. Mais importante é a criatividade gerada pelas competências humanas e artificiais combinadas, a recombinação de elementos apropriados, as intertextualidades promovidas, a sátira e o riso que se evocam e a viralização que garante a longevidade do replicador.

Resgatando a escala da abstração proposta por Flusser, no caso das imagens préfotográficas, a tridimensionalidade do real, com suas formas e volumes, era transformada em "circunstância" objetiva pela ação humana direta. Depois, os fenômenos passaram a ser registrados com bidimensionalidade em forma de cena, abstraída de profundidade. Passamos ao momento da unidimensionalidade da escrita, o que torna as cenas narráveis. No último estágio de abstração, encontramos a dimensionalidade zero ou nulodimensionalidade das imagens técnicas digitais, como os memes, que se originam por meio do tatear das teclas com as pontas dos dedos, gesto técnico de reagrupamento de pontos para formar superfícies. Esses gestos se traduzem em apropriação, "remixagem"10, ressignificação e compartilhamento.

Os replicadores meméticos passam por mutações deliberadas, num processo de fusão entre o aparelho - smartphone ou notebook, por exemplo, que são dispositivos fechados, opacos, cujo interior não é acessível, a não ser pela introdução de um input e pelo recebimento de um output - e seu operador - internauta, para o qual pouco importa exatamente o processo que se passa no interior da caixa-preta. Entram em consonância a competência do internauta e a do aparato técnico; o primeiro se apropria ludicamente deste último, a fim de explorar suas potências e os limites de sua programação.

Como num jogo, o usuário dá os comandos e reordena os pontos na tela com criatividade, partindo do imaginário para o real, brincando para gerar novas imagens não redundantes e o mais improváveis possível. No universo dos memes da internet, os internautas atuam como jogadores que brincam com pedaços de informação disponíveis

\footnotetext{
10 Conjunto de práticas sociais e comunicacionais de combinações, montagens e colagens de informação a partir das tecnologias digitais (LEMOS, 2005, p. 1).
} 
(jogo dialógico), recombinando-os e ressignificando-os. Flusser denomina esse jogador de imagens técnicas de "homo ludens" (2011, p. 43), haja vista o jogo ser uma atividade do lúdico.

As novas imagens geradas no jogo entram em um campo de virtualidade que garante, em potência, eternas metamorfoses, tornando-as infinitas porque extremamente manipuláveis (OLIVEIRA, 2016). O interessante da virtualidade é que ela age sem diferenciação entre texto, imagem e som, que se tornam dados computados, informação binária digital, que só nos fará sentido por meio de um aparelho.

É certo que as técnicas de edição e montagem de imagens são anteriores à internet, mas as novas tecnologias da comunicação tornam a sua aplicação mais fácil, até mesmo corriqueira e trivial, seja uma edição simples, seja uma montagem mais elaborada. 0 digital amplia as possibilidades de produção e manipulação. Isso ocorre nas fotografias pessoais feitas com aparelhos mobile e compartilhadas em mídias sociais, nas quais é instintivo e naturalizado o processo de editar tal imagem, nem que seja através de filtros ou templates, o que democratiza tais processos inclusive para os usuários inexperientes. 0 mesmo se dá com memes que circulam na internet, que podem requerer tanto comandos mais simples, como cortar, colar, adicionar palavras ou ícones, quanto mais sofisticados, como é o caso de deep fakes ${ }^{11}$.

A circulação de memes na web promove a troca de informação entre humanos por intermédio de imagens. No contexto da "sociedade humorística" de Lipovetsky e de uma nova economia simbólica instaurada pela infografia, proliferam as páginas e perfis de humor nas redes sociais, objetivando espalhar o máximo de unidades ao máximo de indivíduos. A linha entre produtores e consumidores se torna cada vez mais tênue e borrada, dispensando a dicotomia.

Dentro dessa economia simbólica, cada pessoa é como um nó entre um emaranhado de fios (a formar uma extensa rede que nos conecta), pelos quais a informação entra e é processada, armazenada e transmitida, explica Flusser (2014). Para o autor, há "uma conectividade em rede que se espalha como um cérebro ao redor do globo terrestre, sendo que os canais são os nervos, e os nós são as pessoas e os aparelhos" (FLUSSER, 2014, p.

\footnotetext{
11 Técnica de síntese de imagens ou sons humanos baseada em inteligência artificial, geralmente usada para combinar fala e/ou rosto a um vídeo preexistente, atribuindo ações a pessoas que na verdade não as fizeram ou discursos a pessoas que na verdade não os disseram. Quanto maior o grau de sofisticação do produto final, mais fácil enganar pessoas desavisadas ou ingênuas. As deep fakes são frequentemente usadas para vídeos falsos de caráter sexual ou para espalhar fake news.
} 
276); há também um cruzamento de competências a fim de secretar novas informações para aumentar a competência total desse "cérebro".

Esses pensamentos convergem para a concepção de inteligência coletiva mencionada anteriormente. Na sociedade telemática, predomina um intercâmbio informacional dialógico através de imagens, na busca constante pela aventura informacional do novo, pela geração de novas imagens improváveis.

Flusser entende o surgimento e avanço das imagens técnicas como uma "[...] revolução epistemológica, ético-política e estética" (2008, p. 45), e os revolucionários seriam aqueles que lidam com as tecnoimagens, desde fotógrafos, filmadores, programadores e designers até produtores de memes na web. Tanto os aparelhos quanto as imagens técnicas podem ser usadas, portanto, não apenas para o entretenimento, mas também para fins políticos, culturais e sociais.

\section{Considerações finais}

Enquanto imagens técnicas, os memes são entidades virtuais, sem corporeidade ou materialidade física, do grau zero de dimensão, formados pelo reagrupamento intencional de pontos em superfícies eletrônicas através de comandos acionados pelo toque das pontas dos dedos sobre teclas. Necessitam, obrigatoriamente, de um aparelho técnico, embora o produtor do conteúdo não precise saber da mágica que se dá dentro da caixa-preta préprogramada.

Os memes, cuja atividade primordial é a replicação, encontram no meio digital e na internet, especialmente através dos softwares e aplicativos de edição como também das redes sociais, ambiente perfeito para se disseminarem. No contexto da sociedade humorística, apontada por Lipovetsky, e da sociedade telemática, calcada numa cultura da imagem, discutida por Flusser, desenvolve-se uma nova forma de pensar os fenômenos, um novo modo de escrever, uma nova maneira de se expressar diante das questões humanas, um novo jeito de se relacionar socialmente, um novo modelo de trocas, de compartilhamento: a comunicação mediada por memes da internet.

Essa mediação não se dá apenas no ambiente online: extrapola o ciberespaço e se infiltra no cotidiano humano, dissolvendo-se em nossas práticas sociais. Memes surgem a todo momento, nas redes, e passam a ser usados em diálogos face a face, ou surgem de 
diálogos face a face e passam a ser amplamente replicados nas redes. 0 uso de memes na comunicação se tornou uma espécie de dispositivo linguístico, mediando relações.

Os memes estão nas propagandas políticas, na publicidade, nas músicas, nas novelas, em podcasts, em programas de TV e em tantos outros espaços físicos e virtuais. 0 produtor de memes é um eterno homo ludens a usar as pontas de seus dedos para brincar de recombinar comandos automatizados, e, dentro da nova economia simbólica promovida pela infografia, a ludicidade dos memes pode se converter em moeda de venda e troca de produtos, serviços e ideias.

Os memes surgem da criatividade gerada pelas competências humanas e artificiais combinadas. É no nível de consciência imaginativo que os internautas, de maneira extremamente criativa, codificam as circunstâncias, os fenômenos sociais (a política nacional, a relação com outros países, estereótipos de uma profissão ou hábitos do brasileiro, por exemplo) em símbolos, dando origem a tecnoimagens na forma de memes, que se espalharão pelo ciberespaço e serão decodificadas de símbolos para circunstâncias, por outros tantos internautas que consumirem tal conteúdo.

Na sociedade pós-moderna, não basta que os indivíduos sejam alfabetizados na língua textual. É imprescindível, para a vida social em rede, na era da pós-história, ser alfabetizado em imagens, em tecnoimagens, haja vista o avanço das imagens técnicas no contexto da revolução epistemológica, ético-política e estética pela qual estamos passando.

É no fluir das imagens técnicas entre os nós, através de fios emaranhados, que Flusser acredita ser possível existir uma cultura da imagem, e na sociedade telemática de que fala o filósofo, há um universo frenético de imagens técnicas intermediando diálogos cibernéticos e estabelecendo um império imaginístico criativo, espaço no qual os memes reinam.

\section{Referências}

BENJAMIN, Walter. A obra de arte na era de sua reprodutibilidade técnica. Porto Alegre: L\&PM, 2015.

BLACKMORE, Susan. The meme machine. Oxford: Oxford University Press, 2000.

DAWKINS, Richard. 0 gene egoísta. São Paulo: Companhia das Letras, 2007. 
FLUSSER, Vilém. 0 universo das imagens técnicas: elogio da superficialidade. São Paulo: Annablume, 2008.

FLUSSER, Vilém. Filosofia da caixa preta: ensaios para uma futura filosofia da fotografia. São Paulo: Annablume, 2011.

FLUSSER, Vilém. Comunicologia: reflexões sobre o futuro: as conferências de Bochum. São Paulo: Martins Fontes, 2014.

FONTANELLA, Fernando. 0 que é um meme na Internet? Proposta para uma problemática da memesfera. In: Simpósio Nacional da ABCiber, 3., 2009, São Paulo. Anais [...]. São Paulo: ABCiber, 2009.

JENKINS, Henry. Cultura da convergência: a colisão entre os velhos e novos meios de comunicação. Tradução de Susana Alexandria. 2. ed. São Paulo: Aleph, 2009.

LEMOS, André. Ciber-cultura-remix. Seminário sentidos e processos. São Paulo: Itaú Cultural, 2005.

LIPOVETSKY, Gilles. A sociedade humorística. In: LIPOVETSKY, Gilles. A era do vazio. Barueri: Manole, 2005.

OLIVEIRA, Juracy. A imagem técnico-memética no Facebook. 2016. Dissertação (Mestrado em Comunicação) - Programa de Pós-graduação em Comunicação, Universidade do Estado do Rio de Janeiro, Rio de Janeiro, 2016.

PRIMO, Alex. Digital trash e lixo midiático: a cauda longa da micromídia digital. In: PEREIRA, Vinicius Andrade (org.). Cultura digital trash: linguagens, comportamentos, entretenimento e consumo. Rio de Janeiro: E-papers, 2007.

SANTAELLA, Lucia; NÖTH, Winfried. Imagem: cognição, semiótica, mídia. São Paulo: Iluminuras, 2013.

SHIFMAN, Limor. Memes in digital culture. Cambridge: MIT Press, 2013.

SODRÉ, Muniz; PAIVA, Raquel. 0 império do grotesco. Rio de Janeiro: Mauad, 2002.

\title{
Memes as technoimages: a discussion in light of Vilém Flusser's ideas
}

\begin{abstract}
Memes are replicant and viral cultural elements that have become immensely popular on the internet, and their creation, consumption and spread has become a social practice among internet users. This article, through bibliographic research, aims to understand and discuss the meme phenomenon in light of the ideas of the philosopher Vilém Flusser about images in
\end{abstract}


postmodernity, which he calls "technical images" or "thecnoimages". Internet memes, thus, are presented as a form of language typical of postmodern communication and as a digital culture practice within what the philosopher calls posthistory.

\section{Keywords}

Media. Meme. Technical images. Technoimages. Flusser.

Recebido em 30/04/2020

Aceito em 08/05/2020 